\title{
DETERMINASI EKSISTENSIAL PEMIKIRAN HUKUM ISLAM ABDULLAHI AHMED AN-NA‘IM
}

\author{
Tholkhatul Khoir \\ Universitas Islam Negeri Walisongo Semarang, Indonesia \\ E-mail: papathol@yahoo.com
}

\begin{abstract}
This article deals with the Islamic legal thought of Abdullahi Ahmed an-Na'im from the sociology of knowledge approach. According to this approach, knowledge (including religious interpretation and practices) is sociologically, economically and politically determined. This


thought is determined by his existence within social reality. This article concludes that an-Na'im's thought is determined by (1) socio-political and legal reality in Sudan, (2) Mahmoud Mohamed Taha who influenced his ideas, (3) British milieu, and (4) American environment which is politically secular, Islamo-phobic, racist, discriminative and intolerant towards Afro-Americans. The maturity of an-Na'im's thought is particularly influenced by the history of British colonialism in Sudan and his academic training in England, a place where human rights discourse develops as the result of postenlightenment humanism and some major revolutions in Europe.
\end{abstract}

Keywords: Sociology of knowledge; existential determinism; Sudan; Britain; America.

\section{Pendahuluan}

Nama lengkap tokoh yang sedang dikaji dalam penelitian ini adalah Abdullahi Ahmed an-Na'im. Ia lahir di Sudan pada tanggal 19 Nopember 1946. Pendidikan dasar sampai pendidikan sarjananya ditempuh di negaranya sendiri, Sudan. Sedang studi magister dan program doktor dilaluinya di luar negeri. Sejak muda, an-Na'im memiliki minat yang kuat dalam bidang hukum, termasuk hukum Islam. Konsep-konsep dan pemikiran hukum Islam dipelajari secara saksama pada seluruh jenjang pendidikan yang ditempuhnya, dan 
secara lebih sistematik, pada Fakultas Hukum Universitas Khartoum, Sudan. ${ }^{1}$

Pada tahun 1970, an-Na'im berhasil menyelesaikan studi di fakultas tersebut dengan mendapat gelar LL.B. Pada tahu 1971, ia melanjutkan studi pada Program Pascasarjana (S2) ke Universitas Cambridge Inggris, dengan mengambil spesialisasi tentang hak-hak sipil, konstitusi negara-negara berkembang dan hukum privat internasional (The Law Relating to Civil Liberties, Constitutional Law of Developing Countries and Private International Law). Ia berhasil memeroleh gelar LL.M. pada 1973, dengan karya ilmiah berjudul Judical Review of Administrative Action: the Law Relating to Civil Liberties, Constitutional Law of Developing Countries and Private International Law. Pada tahun dan di universitas yang sama, ia juga mengambil program magister bidang kriminologi, dengan menulis karya ilmiah berjudul Criminal Process, Penology, Sociology of Crime and Research Methodology. Sedangkan program doktor (Ph.D.) ditempuhnya di Universitas Edinburg, Skotlandia, dalam bidang hukum pada 1976, dengan disertasi mengenai perbandingan prosedur pra-peradilan kriminal antara hukum Inggris, Skotlandia, Amerika Serikat, dan Sudan (Comparative pre-Trial Criminal Procedure: English, Scottish, U.S. and Sudanese Law). Setamat S3-nya, an$\mathrm{Na}$ im kembali ke Sudan dan bekerja sebagai dosen di almamaternya, University of Khartoum sejak bulan Nopember 1976 hingga 1985.

Sejak tahun 1985 sampai dengan 1992, ia menjadi visiting professor di beberapa universitas di benua Amerika, Afrika, dan Eropa, yaitu: Agustus 1985 hingga Juli 1987, menjadi visiting professor of law di School of Law University of California di Los Angeles (UCLA); Agustus 1988 hingga Januari 1991, menjadi arief a sallows professor of human right di College of Law, University of Saskatchewan di Canada; Agustus 1991 hingga Juni 1992, menjadi Olof Palme visiting professor di Faculty of Law, Uppsala University di Swedia; Juli 1992 hingga Juni 1993, menjadi scholar in residence di The Ford Foundation Office for the Middle East and North Africa di Cairo Mesir. Pada periode yang sama, ia juga menjadi executive director of human right watch/Africa di Washington DC Amerika

\footnotetext{
1 Berkenaan dengan minatnya terhadap hukum Islam, an-Nacim mengatakan: $A s$ Sudanese Muslim, I grew up learning about shari'a throughout the stages of school, and as a subject of systematic study at the Faculty of Law, University of Khartoum, Sudan, some thirty years ago." Lihat Abdullahi Ahmed an-Na'im, "Shari'a and Positive Legislation: Is an Islamic State Possible or Viable?", Makalah Public Lecture The Application of Shari"ah and The Issue of Human Rights in Muslim World, UIN Syarif Hidayatullah Jakarta, 4 Januari 2003, 1-2.
} 
Serikat; dan mulai Juni 1995, ia secara resmi menjadi warga negara Amerika dan sampai sekarang diangkat dan bekerja sebagai guru besar di bidang hukum Fakultas Hukum di Universitas Emory yang terletak di kota Atlanta Georgia, sebuah negara bagian Amerika Serikat. ${ }^{2}$

Penelitian ini mengkaji pemikiran hukum Islam an-Na'im dengan pendekatan sosiologi pengetahuan (sociology of knowledge). Metode jenis ini sengaja dipilih karena an-Na'im adalah satu di antara sekian pemikir yang meyakini bahwa penerapan aspek-aspek hukum publik sharî́ah akan menimbulkan kesulitan. Hal ini terbukti oleh kenyataan bahwa hukum publik merupakan aspek sharî‘ah yang paling kurang dikembangkan. An-Naim adalah salah satu orang yang mengatakan bahwa shari'ah ternyata "tidak memadai dan tidak adil" itu. Ia sendiri juga menyatakan bahwa penafsiran dan praktik semua agama, termasuk Islam, sangat ditentukan oleh kondisi sosiologis, ekonomi, dan politik masyarakat tertentu. Karena itulah, penelitian terhadapnya sah dilakukan. Penelitian ini bermaksud mengetahui bagaimana pemikiran an-Na'im ditentukan oleh realitas sosialnya. Untuk menjawab persoalan itu, peneliti menggunakan pendekatan yang khas membedah persoalan hubungan antara pemikiran dan keberadaan pemikir dalam realitas sosial, yaitu sociology of knowledge.

\section{Maksud Determinasi Eksistensial}

Sebelum berbicara tentang determinasi eksistensial, sosiologi pengetahuan lebih dahulu harus dibicarakan. Sosiologi pengetahuan adalah cabang termuda sosiologi yang mengembangkan suatu teori tentang makna faktor-faktor non-teoretis yang menentukan pemikiran an-Na im. Dalam penelitian ini, sosiologi pengetahuan digunakan untuk mengetahui bagaimana perspektif, atau cara an-Naim mengetahui hukum Islam, ditentukan oleh latar belakang sosial dan historisnya. Karena itu, tugas peneliti adalah mengkaji bagaimana realitas sosial an-Na'im memengaruhi atau berhubungan secara timbal balik dengan pemikirannya. Hal ini sebagaimana kata Berger dan Luckmann bahwa realitas sosial berada dalam hubungan timbal balik yang dialektis dan menguntungkan. ${ }^{3}$

\footnotetext{
2 http:/ /www.law.emory.edu/aannaim/diakses tanggal 29 Oktober 2014.

3 Peter Berger dan Thomas Luckmann, The Social Construction of Social Reality: A Treatise in the Sociology of Knowledge (England: Penguin Books, 1966), 180.
} 
Dalam bahasa Mannheim, sosiologi pengetahuan mengandaikan analisis terhadap hubungan antara pengetahuan dan eksistensi, ${ }^{4}$ (tepatnya antara pemikiran an-Na im tentang hukum Islam dan yang lain-lain, dengan basis eksistensial an-Na'im di Khartoum Sudan, Cambridge Inggris, Edinburgh Skotlandia, dan Atlanta Georgia). Atau mengikuti Stark, bahwa sosiologi pengetahuan sesungguhnya melakukan analisis tentang bagaimana dan dalam bentuk apa kehidupan intelektual (an-Naim) dalam momen sejarah tertentu direlasikan dengan kekuatan politik dan sosial yang ada. Hal ini dikarenakan bukan kesadaran an-Na'im yang menentukan eksistensi, tetapi sebaliknya, eksistensi sosialnya yang menentukan kesadarannya. ${ }^{5}$ Atau mengikuti Sprott, sosiologi pengetahuan memusatkan perhatian pada cara-cara di mana sistem pemikiran an-Na'im dikondisikan oleh faktor-faktor sosial yang lain. ${ }^{6}$

Mannheim juga mengatakan bahwa langkah sosiologi pengetahuan tidak lain adalah membedakan dan mengisolasi gaya pemikiran an-Na'im yang beraneka ragam dan menghubungkannya dengan kelompok lain di mana pemikiran itu (pemikiran an-Na'im) bersemi. Kemudian sesuai dengan otoritas yang sama, dinyatakan oleh sosiologi pengetahuan bahwa ide-ide yang diekspresikan itu-oleh an$\mathrm{Na}$ im-dianggap sebagai fungsi dari eksistensi sosialnya. ${ }^{7}$

Sebagai sebuah fakta konkret, istilah determinasi eksistensial atas pengetahuan paling baik didekati dengan sebuah ilustrasi. Determinasi eksistensial atas pemikiran bisa dianggap sebagai suatu fakta, jika: a) bahwa proses mengetahui betul-betul tidak berkembang secara historis sesuai dengan hukum-hukum yang imanen, bahwa proses itu tidak hanya berlangsung dari "hakikat benda-benda" atau dari "kemungkinan-kemungkinan logis murni", dan bahwa proses itu tidak didorong oleh "dialektika dalam". Sebaliknya, munculnya atau kristalisasi suatu pemikiran dalam banyak sudut yang menentukan, ditentukan oleh faktor-faktor ekstra teoretis yang sangat beraneka ragam. Dalam kontra distingsinya dengan faktor-faktor teoretis murni,

${ }^{4}$ Karl Mannheim, Ideologi dan Utopia: Menyingkap Kaitan Pikiran dan Politik, terj. F. Budi Hardiman (Yogyakarta: Kanisius, 1991), 237.

5 A Contribution to the Critique of Political Economy, trans. Stone, 1913, $11 \mathrm{seg}$, sebagaimana dikutip dalam Warner Stark, The Sociology of Knowledge: An Essay in Aid of a Deeper Understanding of the History of Ideas (London: Routledge, 1998), 12.

6 Sprott, Science and Social Action, 1954, 141, sebagaimana dikutip dalam Warner Stark, The Sociology, 13.

${ }^{7}$ Mannheim, Ideologi dan Utopia, 45-50. 
hal itu dapat disebut faktor eksistensial; b) bahwa pengaruh faktorfaktor eksistensial terhadap isi konkret pemikiran itu merupakan pengaruh yang lebih dari pada sekadar pengaruh yang bersifat periferis, jika faktor-faktor itu relevan tidak hanya untuk asal-usul, melainkan juga merasuk ke dalam bentuk-bentuk dan isi pemikiran itu, dan jika faktor-faktor itu sedemikian menentukan cakupan dan intensitas pengalaman an- $\mathrm{Na}^{\text {'im. }}$.

Sebagai contoh akan peneliti perlihatkan bagaimana posisi sosial memengaruhi pemikiran. Konsep liberal tentang kebebasan adalah suatu konsep dari sebuah kelompok yang berusaha menggulingkan tatanan sosial eksternal, legal dan non-ekualiter. Gagasan konservatif tentang kebebasan, di lain pihak, adalah gagasan dari suatu lapisan yang tidak ingin melihat perubahan apapun dalam tatanan lahiriah kenyataan, berharap bahwa peristiwa-peristiwa akan berlangsung terus dalam keunikan tradisionalnya, agar dapat menopang kenyataan sebagaimana adanya. Mereka juga harus mengalihkan isu-isu mengenai kebebasan di bidang politik lahiriah ke dalam bidang non-politis batiniah. Bahwa kaum liberal hanya melihat sisi yang satu, dan kaum konservatif hanya melihat sisi yang lain dari konsep dan masalah yang jelas-jelas berkaitan dengan posisi mereka masing-masing dalam struktur sosial dan politis.

Posisi sosial tidak dapat dijelaskan dalam istilah-istilah yang dikosongkan dari makna-makna sosial seperti misalnya uraian kronologis semata. Tahun 1983 atau 1985, misalnya, sebagai tanggal kronologis tidak bermakna. Akan tetapi, sebagai uraian kronologis, tanggal ini mengacu kepada seperangkat peristiwa (baca: penerapan sharî‘'ah secara penuh di Sudan dan eksekusi hukuman mati Taha) yang bermakna, yang di dalam dirinya membatasi cakupan jenis pengalaman tertentu, konflik, sikap, dan pemikiran an-Na'im.

Untuk keperluan di atas itulah, maka perlu diketahui bagaimana pemikiran dan kehidupan sosial masyarakat Sudan, Maḥmûd Muhammad Taha sebagai guru an-Na'im, Cambridge Inggris, Edinburgh Skotlandia, dan Atlanta USA sebagaimana dijelaskan di atas, membentuk pemikiran an-Na'im.

\section{Pemikiran Hukum Islam Abdullahi Ahmed an-Na'im}

Beberapa karya an-Na'im yang dapat diakses oleh penelitian ini adalah: pertama, Toward an Islamic Reformation: Civil Liberties, Human Rights, and International Law. Mengikuti Farish A. Noor, dalam buku ini an-Na'im mengritik kontradiksi-kontradiksi yang ditemukan di 
berbagai negara berkaitan dengan upaya "Islamisasi negara" yang mereka lakukan, khususnya hak-hak yang diberikan kepada nonMuslim oleh negara Islam yang mereka dambakan. An-Na'im mengatakan bahwa berbagai kontradiksi yang ada sesungguhnya mencerminkan adanya problem fundamental yang dihadapi oleh para pemikir Islam dogmatik konservatif dan para praktisi yang hanya berpijak pada interpretasi literal sharî‘ ah belaka. ${ }^{8}$

Kedua, Islamic Law Reform and Human Rights: Challanges and Rejoinders. Karya ini sebenarnya bukan tulisan an-Na'im sendiri, melainkan kumpulan dari beberapa penulis seperti: Mohammed Arkoun, Roy P. Mottahedeh, Ann Elizabeth Mayer, Ishtiaq Ahmed, Bassam Tibi, Khalid Duran, Farid Esack, Payam Akhavan, Noura Kirabaev, Arthur Sagadeev, Helge Hoibraaten, dan tentunya an-Na'im sendiri. Selain itu, peneliti hanya berkesempatan mendapatkan edisi terjemah Indonesianya yang diterbitkan oleh LKiS Yogyakarta cetakan II tahun 2009, dengan judul Dekonstruksi Sharíah II. Tulisantulisan yang dimuat dalam buku ini merupakan hasil revisi dan perluasan dari makalah yang disajikan pada seminar tentang Hak Asasi Manusia dan Aplikasi Hukum Islam di Dunia Modern yang diselenggarakan oleh Norwegian Institute of Human Rights (NIHR), Oslo, 14-15 Februari 1992. Faktor utama diadakannya seminar Oslo adalah terbitnya buku an-Na'im yang berjudul Toward an Islamic Reformation: Civil Liberties, Human Rights, and International Law. Dalam buku tersebut, an-Na'im mengangkat beberapa persoalan penting yang belum terpecahkan. Sedang maksud diadakannya seminar Oslo tidak lain adalah membahas cara-cara menghadapi berbagai tantangan normatif mendasar yang muncul akibat perjumpaan antara tradisi Islam dan modernitas, baik dari sudut pandang teoretis maupun terapan, dengan lebih memusatkan perhatian pada metodologi dan substansi dari pada masalah-masalah teknis hukum.

Ketiga, Proselytization and Communal Self-Determination in Africa. Buku ini adalah judul ketiga yang dipublikasikan dalam seri Religion and Human Right oleh Law and Religion Program of Emory University. Dua judul sebelumnya membahas tentang Eropa Timur dan Amerika Latin. Ketiga judul itu bersama-sama menyajikan bukti bahwa hubungan antara agama dan HAM adalah problematik dan tidak

${ }^{8}$ Farish A. Noor, "Review Book: Toward an Islamic Reformation: Civil Liberties, Human Right, and International Law", Journal of Muslim Minority Affairs; Pro Quest Religion, Vol. 20, No. 2 (Oktober 2002), 376-378. 
terelakkan di seluruh bagian dunia. ${ }^{9}$ Isu tentang pindah agama dan penentuan nasib sendiri di Afrika diuraikan dalam sebelas bab, didahului dengan kata pengantar oleh an-Na'im sebagai editor. Isi buku ini menyajikan pertimbangan teoretis bagi aspek-aspek politis, hukum, dan religius dalam kasus pindah agama. Sebuah studi terhadap kasus dimaksud terjadi di Kongo, Sudan, Mali, Nigeria, Ghana, Kenya, dan Algeria. Para penulis buku ini adalah J. Paul Martin, Harry Winter, Farid Esack, Lamin Sanneh, Francis M. Deng, Benjamin F. Soares, Rosaling I.J. Hackett, Hannah W. Kinoti, dan Chabha Bouslimani. Mereka diminta memberikan kontribusi karena dianggap mengerti lebih tentang kompleksitas pindah agama dalam konteks Afrika masa kini. ${ }^{10}$ Apa yang sedang dicari buku ini adalah etika pemindahan agama yang berkaitan dengan dua HAM yang seringkali berbenturan: kebebasan beragama dan perlindungan terhadap komunitas sendiri. Argumen an-Na'im dan para kontributor yang menyatakan bahwa negara harus memainkan perannya dalam memimpin negosiasi keseimbangan ini menempatkan buku ini dalam urutan pertama daftar bacaan orang-orang yang sedang mengikuti perkembangan gereja dan negara secara global.

Keempat, African Constitutionalism and the Contingent Role of Islam. Karya ini diterbitkan di Philadelphia oleh University of Pennsylvania Press pada tahun 2006. Dalam karya ini, an-Na'im menjelaskan bagaimana dialog antara konstitusionalisme modern di satu pihak, dan pengaruh kolonialis yang masih tersisa di Afrika di pihak lain. Bagaimana pula dialognya dengan prinsip-prinsip Islam. "Bagaimana konstitusionalisme berhadapan dengan efek kolonialisme yang tetap hidup? Bagaimana hukum konstitusional Afrika berhadapan dengan ajaran Islam?" katanya. Terhadap pertanyaan-pertanyaan di atas, an$\mathrm{Na}$ 'im berpendapat bahwa konstitusionalisme memang masih menjadi bentuk yang lazim dalam pemerintahan di negara-negara Afrika. Konstitusionalisme Afrika dan ajaran Islam masih mencari jawaban atas pertanyaan di atas. Sebuah negara konstitusional Afrika, seperti sekarang ini, tidak mudah dicapai tanpa proses adaptasi yang panjang. Prinsip-prinsip Islam sesungguhnya menerima tantangan dan perubahan ini tanpa harus dikonotasikan negatif atau positif. Pengelolaan negara secara konstitusional belum dan tidak akan

\footnotetext{
${ }_{9}$ Abdullahi Ahmed an-Na'im (ed.), Proselytization and Communal Self-Determination in Africa (New York: Orbis Books, 1999), vii.

${ }^{10}$ Ibid., 23.
} 
mendapatkan jawaban itu dengan mudah. Tetapi ia yakin bahwa kesulitan-kesulitan memecahkan persoalan di atas hanyalah terjadi dalam proses adaptasi dan pribumisasi konsep nation state, yang secara esensial masih teralienasi itu, berikut aturan-aturannya dalam skala politik dan organisasi sosial yang besar.

Kelima, Islam and the Secular State: Negotiating the Future of Shari'a. Buku ini diterbitkan dalam banyak bahasa termasuk Indonesia. Edisi Inggrisnya diterbitkan di Cambridge and London oleh Harvard University Press, pada tahun 2008. Sedang edisi Indonesianya diterbitkan di Bandung oleh Penerbit Mizan pada tahun 2007 dengan judul Islam dan Negara Syariab: Menegosiasikan Masa Depan Syariah. Inti pertanyaan penelitian buku ini, menurut peneliti, adalah: Apakah Islam mendukung ide pemisahan antara negara dan agama? Menurut an-Naim, pemisahan antara agama (dalam hal ini, Islam) dan negara bukan berarti tidak memberikan peran pada Islam dalam kebijakan publik, perundang-undangan atau kehidupan publik secara umum. Namun peran itu harus didukung oleh apa yang disebut an-Na'im sebagai "nalar publik" dan harus tunduk kepada perisai-perisai konstitusional serta pelindungan hak-hak asasi manusia. Dilihat dari tujuannya, sharî‘ah hanya bisa dijalankan dengan sukarela oleh penganutnya. Sebaliknya prinsip-prinsip sharî́ah akan kehilangan otoritas dan nilai agamanya apabila dipaksakan oleh negara. Oleh karena itu, pemisahan Islam dan negara secara kelembagaan sangat diperlukan agar sharî‘ah bisa berperan positif dan mencerahkan bagi kehidupan umat dan masyarakat Islam.

Pemikiran hukum Islam an-Na'im secara sistematis dapat dipetakan sebagai berikut.

\section{Reformasi Sharî‘ah}

Sharî'ah memang sudah menjadi mindset mayoritas umat Islam secara umum. Mengapa demikian, karena para ulama telah menjadikannya sebagai body hukum Islam yang tidak dapat ditolak dan dipertanyakan umat Islam berikutnya. Menurut an-Na'im, sepanjang aspek hukum publik sharî́ah terus diangap sebagai satu-satunya pandangan hukum yang valid, maka umat Islam akan menemui berbagai kesulitan ekstrim untuk menerapkannya atau sebaliknya mereka akan menolak memraktikkannya. Sharî‘ah tidak lain adalah produk sejarah, di mana ulama-ulama terdahulu mengadopsi dan beradaptasi dalam rangka menyesuaikan kebutuhan masyarakat Muslim. Hal ini tercermin dalam kenyataan bahwa sharî‘ ah sangat 
kuat dalam hukum keluarga dan privat, tetapi lemah dalam hukum pidana dan tata negara.

\section{Penegakan Hak Asasi Manusia}

Salah satu alasan reformasi sharî́ah yang dipikirkan an-Na'im adalah bahwa sharî́ah historis sudah tidak relevan dengan prinsipprinsip Hak Asasi Manusia Internasional. Sebagai hasil interpretasi, perspektif sharî‘ah tentang HAM akan beragam sesuai dengan interpretasi dan penafsiran orang, baik terhadap teks al-Qur'ân dan alSunnah, maupun terhadap teks HAM itu sendiri. Dengan demikian dapat dikatakan bahwa pandangan sharî‘ah tentang HAM (sama halnya dengan pandangan sharî́ah tentang riba, narkoba, atau apa saja), hakikatnya adalah pandangan seseorang tentang sharî'ah dan beberapa masalah tersebut; atau pandangan orang tentang HAM setelah ia memahami dan menafsirkan nass yang berhubungan dengan masalah bersangkutan. Dari sini dapat dimengerti, mengapa kemudian terjadi khilâfíyah.

Di dalam al-Qur'ân terdapat ayat-ayat yang dapat dipandang relevan dan memberi dukungan pada tegaknya hak asasi manusia. Akan tetapi, di samping itu terdapat pula beberapa ayat yang dapat dikategorikan bertentangan dan tidak mendukung hak asasi manusia. Ayat-ayat dan pemahaman terhadapnya yang mengakui kesetaraan laki-laki dan perempuan, serta memberi kesempatan yang sama kepada mereka untuk mendapat kedudukan tertinggi di hadapan Tuhan, di antaranya adalah: Q.S. al-Nahl [16]: 97. Demikian juga ayat yang memberi kebebasan beragama seperti pada Q.S. al-Baqarah [2]: 256. Sementara ayat-ayat dan pemahaman terhadapnya, yang tidak toleran adalah Q.S. al-Tawbah [9]: 29; Q.S. al-Nisâ' [4]: 2 tentang poligami, Q.S. al-Mầidah [4]: 5 tentang kebolehan laki-laki Muslim menikahi perempuan Ahli Kitab; dan Q.S. al-Baqarah [2]: 221 tentang larangan menikahi orang musyrik.

Menurut an-Na'im, formula sharî́ah yang berkembang luas di dunia Islam selama ini lebih diwarnai oleh ayat-ayat dan pahampaham yang mendukung: pertama, perbedaan hak dan perlakuan hukum antara laki-laki dengan perempuan; kedua, perbedaan hak dan perlakuan hukum antara Muslim dengan non-Muslim; ketiga, tidak adanya kebebasan beragama yang dibuktikan dengan hukuman fisik yang kejam bagi pelaku riddab; keempat, jihad sebagai pengerahan kekuatan terhadap negara lain yang non-Muslim; kelima, perbudakan karena memang tidak ada satu nașs pun yang melarangnya. 
Kelima hal di atas dipandang sebagai sesuatu yang seharusnya demikian menurut sharî‘ah; sebagai sesuatu yang qat ‘̂̀ $^{\prime}$ yang tidak mungkin lagi untuk dirubah. Barulah belakangan muncul gugatan dan tuntutan agar formula sharî‘ah yang demikian itu direformasi karena dipandang sudah tidak relevan dengan perkembangan zaman, dan dinilai tidak kondusif bagi penegakan hak asasi manusia yang menjadi tuntutan global dewasa ini. Gugatan dan tuntutan inilah yang dilakukan oleh an-Na'im.

Dalam hal penegakan hak asasi manusia ini, pemikiran an-Na'im, dapat dipetakan menjadi tiga: pertama, kesetaraan laki-laki dan perempuan dalam konteks hukum keluarga. An-Na'im mengatakan bahwa persoalan kepemimpinan rumah tangga dalam hukum Islam perlu dilakukan perubahan untuk menjawab situasi dan kondisi saat ini. Sebab kepemimpinan yang paternalistik dalam kehidupan rumah tangga lebih merupakan respons aktual hukum Islam dalam menjawab kenyataan abad ketujuh dari pada respons ideal hukum Islam, sehingga situasi dan kondisi saat ini juga membutuhkan rumusanrumusan peraturan hukum yang memiliki semangat kekinian dan aplikatif. Rumusan peraturan hukum keluarga di masa kini tidak harus sama dengan rumusan peraturan hukum Islam di masa silam.

Adapun rumusan peraturan hukum Islam yang memiliki semangat kekinian dalam hukum keluarga adalah: pertama, perlunya keterbukaan dan kesetaraan dalam kepemimpinan rumah tangga, sehingga kepemimpinan yang diperlukan sebenarnya bukan monopoli pihak laki-laki atau suami saja, tetapi kepemimpinan kolektif yang mencerminkan kerjasama dan kebersamaan dalam menentukan sikap dan mengatur kehidupan rumah tangga. Ini berarti mereka berdua tidak perlu saling menjatuhkan atau mengalahkan, tetapi saling melengkapi. Kedua, dalam persoalan perceraian, laki-laki atau perempuan harus melakukannya sesuai prosedur hukum formal di pengadilan, sehingga memiliki argumentasi rasional dan dilakukan di muka pengadilan. Ketiga, dalam pembagian warisan, seorang perempuan harus memiliki bagian yang sama dengan bagian laki-laki ketika keduanya berada pada posisi sama dalam hubungannya dengan orang yang meninggal. ${ }^{11}$

Dalam hal pernikahan dan pembagian harta warisan lintas agama, an-Na'im berpendapat: pertama, laki-laki Muslim boleh menikah

11 Abdullahi Ahmed an-Nacim, "Religious Minorities under Islamic Law and the Limits of Cultural Relativisme”, Human Rights Quarterly, 23 (2001), 17-18. 
dengan perempuan Kristen atau Yahudi. Demikian juga laki-laki Kristen dan Yahudi. Kedua, laki-laki dan perempuan Muslim boleh menikah dengan orang-orang kafir (unbelievers), yaitu seseorang yang tidak beriman kepada kitab yang diwahyukan. Ketiga, perbedaan agama tidak menjadi penghalang bagi pewarisan harta, sehingga seorang Muslim dapat mewarisi dari dan mewariskan kepada non-Muslim. Namun semua ketentuan hukum keluarga tersebut baru memiliki kekuatan hukum yang tetap dan mengikat apabila didasarkan pada keputusan kenegaraan. ${ }^{12}$

Kedua, kebebasan beragama dalam konteks hukum pidana. Persoalan-persoalan yang masuk dalam kategori pidana sharî‘ adalah b̧udûd, jinâyât, dan ta'zîr. Menurut an-Na'im, khusus pidana riddah yang masuk dalam kategori hudûd, telah banyak menelan korban. Seperti halnya UU resmi negara Sudan tahun 1983 yang mencantumkan riddah dalam pasal 458 (3). Pasal ini telah menyeret Taha_-sebagai pembaru yang berseberangan dengan wacana dominan umat Islam dan pemerintah-kepada tuduhan murtad, dan dengan alasan ini, ia dijatuhi hukuman mati pada tahun $1985 .{ }^{13}$

Dalam membahas definisi dan spesifikasi hukum pidana sharî́ah ini, an-Na'im memertimbangkan ilmu pengetahuan kontemporer: psikologi, penologi, sosiologi, dan disiplin ilmu pengetahuan lain yang relevan. Masih menurutnya, orang Islam perlu memberikan definisi yang tegas dan tepat agar bisa terhindar dari penyalahgunaan dalam penerapannya. Salah satu cara mengecek ada tidaknya penyelewengan wewenang adalah melalui mekanisme rule of law. Peraturan ini dibuat melalui kebijaksanaan kolektif yang mendasari tindakan untuk memidanakan dan bagaimana menghukumnya melalui proses kriminal, yang menandakan adanya komunitas sebagai keseluruhan, baik Muslim maupun non-Muslim. Mereka harus menerima dan menikmati kebebasan berekspresi dan berserikat serta memiliki akses efektif terhadap formulasi kebijakan itu. Karenanya, kebijakan yang diambil tidak boleh bersifat ekslusif, yang hanya berdasarkan agama,

\footnotetext{
12 Abdullahi Ahmed an-Na'im, "Shari'a and Islamic Family Law: Transition and Transformation", dalam Abdullahi Ahmed an-Na'im (ed.), Islamic Family Law in Changing World: A Global Resource Book (London: Zed Books, 2002), 20.

13 Khalid Duran, "An Alternatif to Islamism: The Evolutionary Thought of Mahmud Taha”, Cross Currents, 42 (Winter 1992), 2; ProQuest Religion, 453-467.
} 
misalnya, tetapi harus memertimbangkan kemanfaatan dan konsensus kelaikan masyarakat secara umum. ${ }^{14}$

An-Na im menegaskan bahwa hukum pidana sangat berpotensi menimbulkan kejahatan kemanusiaan dan pelanggaran Hak Asasi Manusia kalau tidak dihapus. Namun demikian karena tidak ada ayat yang dapat dijadikan landasan untuk menentang ayat-ayat yang sangat eksplisit dan tegas yang menetapkan ḅudûd, maka tidak ada cara yang sah untuk menghapus dan membatalkan hukuman-hukuman tersebut sebagai bagian dari hukum Islam kecuali hanya membatasi aplikasinya dalam praktik. Pilihan ini akan lebih diterima umat Islam dari pada seruan penghapusan total terhadap budûd. ${ }^{15}$

Ketiga, jihad dalam konteks hukum internasional. Dalam hal ini, apa yang menjadi sasaran kritik an-Na'im adalah ajaran tentang jïhâd. Jihâd dalam pengertian al-Qur'ân dan al-Sunnah memiliki pengertian luas tentang pengerahan kekuatan. Ia menyarankan perlunya menelusuri aspek kronologisnya untuk mengetahui realitas yang mengitarinya. Penelusuran ini penting karena telah menolak secara tegas ayat-ayat lain yang justru melarang dan membatasi penggunaan kekuatan. Dari survey ayat-ayat tentang tema dimaksud, an-Na'im menyimpulkan tiga hal: (1) Ayat-ayat yang memerintahkan kekuatan adalah ayat-ayat Madinah. Sebaliknya, ayat-ayat yang memberikan kebebasan beragama dan koeksistensi adalah ayat-ayat Makkah. (2) Ada perkembangan dalam pembenaran al-Qur'ân untuk menggunakan kekuatan mulai dari menahan diri hingga kekuatan penyebaran Islam. Ini bertambah kuat ketika Q.S. al-Tawbah [9] dijadikan landasan oleh ahli hukum perintis untuk menghapus ayat lainnya yang prospektif bagi pembaruan sharî‘ah. Padahal teori interpretasi ini tidak benar. (3) Orang Islam kontemporer yang membela diri dengan mengatakan bahwa sharî'ah awal hanya memertahankan diri dari serangan musuh tidaklah benar. Sebab Islam telah memerintah seluruh Suriah, Irak, Afrika bagian Utara, Spanyol bagian Selatan, Persia, dan India bagian Timur dengan kekuatan penaklukan. ${ }^{16}$

14 Abdullahi Ahmed an-Na'im, Toward an Islamic Reformation: Civil Liberties, Human Rights, and International Law (Syracuse: Syracuse University Press, 1990), 115.

15 Abdullahi Ahmed an-Na'im, "Toward an Islamic Reformation: Responses and Reflections", dalam Tore Lindholm dan Kari Vogt (eds.), Islamic Law Reform: Challenges and Rejoinders (Oslo, Norway: Norwegian Institute of Human Rights, 1993), 108.

16 An-Na'im, Toward an Islamic Reformation, 148. 
Selanjutnya, an-Na'im mengajukan upaya penyelesaian terhadap konsep dâr al-Islâm versus dâr al-ḥarb dan kecenderungan berperang antar negara dengan menekankan perlunya mengikuti hukum internasional modern (PBB) yang mempunyai tujuan dan fungsi fundamental untuk mengatur hubungan sesama anggota komunitas negara internasional sesuai dengan prinsip kesamaan dan keadilan berdasarkan hukum demi menciptakan koeksistensi damai, meningkatkan keamanan dan kesejahteraan negara-negara sarta warganya secara individu. ${ }^{17}$

\section{Menuju Negara Konstitusional}

Hal lain yang menjadi pemikiran an-Naim adalah bahwa semangat penegakan HAM di atas hanya mungkin dilakukan ketika hak-hak yang sudah disepakati secara internasional itu dipahami dan ketika ada agensi yang, menurutnya, berupa negara. Karena itu, negara konstitusionalis menjadi kebutuhan mutlak bagi semangat penegakan HAM dimaksud.

Menurut an-Na'im, konsep negara atau pemerintahan konstitusional tidak hanya sekadar pemerintahan yang sesuai dengan peraturan hukum yang berlaku, tetapi juga harus mampu menciptakan rasa keadilan. ${ }^{18}$ Untuk mencapai tujuan itu, diperlukan beberapa syarat: pertama, penegasan konstitusional akan kesetaraan hak dan kewajiban warga negara. Kedua, adanya upaya untuk berlakunya keseragaman hukum secara nasional dalam kerangka konstitusi. Ketiga, konsisten dengan dua syarat tersebut, harus diundangkan tiadanya diskriminasi agama, ras, maupun ideologi dalam rekruitmen jabatanjabatan kenegaraan atau kepegawaian negara. ${ }^{19}$

\section{Pemisahan antara Agama dan Negara}

Pemikiran terakhir yang diperjuangkan an-Naim adalah pemisahan kelembagaan antara agama dan negara. Pemisahan dimaksud merupakan implikasi dari upaya penegakan HAM yang memang menyaratkan selain pemahaman para aktor internasional, nasional dan lokal tentang HAM, juga yang tidak kalah penting,

\footnotetext{
${ }^{17}$ Ibid., 137.

${ }^{18}$ Ibid., 71.

19 Abdullahi Ahmed An-Naiim, "Eritrean Independence and African Constitutionalism: A Sudanese Perspective", dalam Amare Takle (ed.), Eritrea and Ethiopia: from Conflict to Cooperation (Lawrenceville, NJ, USA: The Red Sea Press, 1994), 115-134, sebagaimana dikutip oleh Moh Mahfud MD, Dasar dan Struktur Ketatanegaraan Indonesia (Yogyakarta: Rineka Cipta, 2001), 71.
} 
menyaratkan adanya sikap respek jurisdiksi domestik negara-negara konstitusional yang telah dipikirkan an-Na'im di atas. Karenanya, memisahkan urusan agama (sharî‘ah) dengan urusan negara sebagai aktor penegak HAM terhadap seluruh warganya yang berbeda-beda agama adalah mutlak adanya. Jika tidak, yang terjadi adalah paradok: di satu sisi negara harus memerjuangkan penerapan sharî‘ah kepada seluruh warganya; di sisi lain ia harus menegakkan HAM yang universal untuk semua manusia. Dengan pertimbangan ini, sekularisme menjadi bagian yang sulit ditinggalkan.

An-Na'im berpendapat bahwa urusan agama bukan urusan negara. Keduanya harus dipisahkan, namun tetap memertahankan hubungan antara Islam dan politik, melalui apa yang disebut sebagai public reason. Prinsip ini memungkinkan penerapan prinsip-prinsip Islam dalam kebijakan publik secara legitimate, namun tetap tunduk pada prinsip-prinsip ketatanegaraan yang berlaku, serta menjamin kesetaraan hak setiap warga negara tanpa membedakan agama, ras, suku, gender, dan ideologi politik.

\section{Empat Eksistensi Penentu Pemikiran an-Na'im}

Peneliti berpendapat bahwa: pertama, keanekaragaman kultur Sudan berpengaruh terhadap pemikiran an-Na'im. Sebagaimana diketahui keanekaragaman kultur merupakan salah satu keistimewaan masyarakat Sudan. Keanekaragaman itu pasti berimplikasi pada keragaman hal-hal lain seperti kehidupan sosial, ekonomi, politik, dan satu lagi khusus persoalan yang dikaji dalam penelitian ini, yaitu pengetahuan. Memang banyak sekali pertanyaan misalnya: Bagaimana keanekaragaman kultur itu menjamin toleransi kehidupan sosial dan memerhalus perselisihan agama dan politik di antara para pemikir? Bagaimana keanekaragaman itu membantu mengembangkan komposisi masyarakat yang saling berinteraksi dalam bayang-bayang munculnya formasi kelas dan kepentingan kelompok? Kemungkinan apa yang ditawarkan oleh keanekaragaman kultur itu untuk membantu mencapai integrasi nasional sebagai ganti dari konflik dan peraturan yang otoriter? Tapi ada satu yang menurut peneliti paling penting, yaitu: bagaimana keanekaragaman itu membuahkan keragaman pemikiran tentang hukum Islam di Sudan?

Mengikuti Mahgoub, peneliti sepakat bahwa apa yang dapat dikatakan sebagai "perselisihan intelektual" di kalangan pemikir Sudan 
itu, sesungguhnya hanya dapat diselesaikan dengan cara menambah kebebasan berpikir itu sendiri. ${ }^{20}$

Untuk membuktikan bahwa di Sudan memang terjadi keragaman berpikir, peneliti mencoba mengambil contoh banyaknya solusi yang ditawarkan dalam menyelesaikan masalah Sudan. Ada yang menyaratkan harus ditegakkannya piagam Charter PBB. Ada yang menginginkan hukum internasional. Ada juga yang berharap dapat memaksimalkan peran agama, Islam dalam hal ini. Persaudaraan Republikan (the Republican Brothers) yang dipimpin Mahmûd Muhammad Taha, misalnya, telah mengajukan wacana hukum internasional dan HAM dengan kontribusi Islam baru.

Keragaman usul di atas menunjukkan keragaman epistemologis. Hal ini juga dikuatkan oleh banyaknya tanggapan atas pemikiran the Republican Brothers itu. Orang Islam ortodoks yang merupakan mayoritas umat Islam di Sudan memandang upaya mistik Taha sebagai sesuatu yang mengacaukan. Kelompok sekularis juga mengritiknya, tetapi masih menghargai pemikiran Taha tentang sosialisme dan concern-nya terhadap nasionalisme. Sebenarnya sedikit sekali di antara mereka yang mengaitkan komunisme untuk menunjuk sosialisme yang diperjuangkan demi tegaknya negara sosialis Sudan. Hanya saja, mayoritas Muslim tradisional tetap menolaknya karena mereka melihat premis umum partai Lenininst-Marxist itu (baca: perjuangan kelas dan peran yang dimainkan kelas pekerja melawan pemilik kapital) sebagai sesuatu yang asing bagi hukum sharî‘ah, meski sebenarnya orang komunis Sudan sendiri memandang pentingnya agama (Islam, dalam hal ini) dalam memberikan petunjuk moral dan spiritual untuk kehidupan yang lebih baik. ${ }^{21}$

Taha dan orang-orang komunis sama-sama memandang bahwa kelompok the Muslim Brotherbood itu reaksioner dan berbahaya bagi orientasi nilai rakyat Sudan dan toleransi agama. Tetapi Taha juga mengritik prinsip komunisme Marx. Sebaliknya, orang-orang komunis menolak dengan kuat ide negara religius sebagaimana dipropagandakan oleh Taha, juga oleh the Moslem Botherhood dan partaipartai tradisional lain.

\footnotetext{
${ }^{20}$ Mahgoub el-Tigani Mahmoud, State and Religion in the Sudan: Sudanese Thinkers (New York: The Edwin Mellen Press, 2003), 180.

${ }^{21}$ Lebih detail, lihat SCP, al-Marxîyah wa Qadâyâ al-Thawrah al-Sûdâniyah (Khartoum: Dâr al-Waṣilah, 1973).
} 
Demikianlah, keragaman berpikir dan sistem keimanan multi religius yang ada di Sudan di atas, termasuk mayoritas Muslim yang ada, memang memengaruhi keragaman epistemologi dan kehidupan sehari-hari. Hanya saja setelah peristiwa demonstrasi besar-besaran pada awal April 1985, para pemikir lebih berhati-hati dalam menyebarkan gagasan dibanding para politisi. Selain itu, para pemikir juga mengakui bahwa pergerakan rakyat sering dihalangi oleh para politisi korup.

Selain keragamaan berpikir di atas, kondisi Sudan yang kurang menguntungkan sedikit banyak membuat an-Na'im kurang nyaman berada di negeri sendiri dan memilih hidup di luar negeri yang iklim akademik dan sosialnya sangat mapan, dan menjanjikan baik bagi pemikiran murni, karir akademik, ekonomi, maupun keamaan dirinya, agar tidak senasib dengan gurunya. Kondisi Sudan yang: pemerintahannya terus-menerus tidak stabil dan seringkali berakhir dengan kudeta militer; selalu menjadi ajang perang saudara antara Utara dan Selatan; memaksakan pemberlakuan sharî‘ah meski ditentang banyak pihak; diliputi genosida di Darfur, Red Sea, Equatoria, dan Nuba; perang pemikiran antara fundamentalis dan modernis; dan terancam, bahkan sudah terjadi, oleh pisahnya separuh wilayah yang ada di Selatan, membuat an- $\mathrm{Na}$ 'im berpikir keras untuk menyelesaikan masalah besarnya itu. Isu-isu yang diusungnya khas menyelesaikan konflik Sudan. Tetapi sebagian besar pemikirannya selalu berseberangan dengan pemikir-pemikir Sudan lain yang hidup di dalam negeri.

Dalam bahasa lain menurut istilah sosiology of knowledge, sesungguhnya bagi kebanyakan umat Islam yang dibesarkan dalam batas-batas sempit "desa"-nya dan menghabiskan seluruh masa hidupnya di tempat kelahirannya, cara berpikir dan berbicara yang khas "desa" itu merupakan sesuatu yang mereka andaikan benar begitu saja. Akan tetapi bagi an-Na'im yang pergi ke "kota" dan sedikit demi sedikit menyesuaikan dirinya terhadap kehidupan "kota", cara hidup dan cara berpikir "desa" tidak lagi menjadi sesuatu yang dibenarkan begitu saja. Ia telah mengambil jarak tertentu dari cara berpikir dan cara hidup itu, dan sekarang, barangkali dengan sadar, ia membedakan antara cara-cara berpikir yang bersifat "desa" dan bersifat "kota". Dalam distingsi ini terdapat permulaan pendekatan yang diusahakan untuk dikembangkan dengan sangat rinci oleh sosiologi pengetahuan. Apa yang diterima oleh kelompok tertentu 
sebagai absolut tampak bagi orang luar sebagai sesuatu yang dikondisikan oleh situasi kelompok dan diketahui sebagai sesuatu yang parsial.

Mengikuti Max Scheler, zaman kita sekarang ini adalah "zaman ekualisasi" (Zietalter des Ausgleichs) yang jika peneliti terapkan dalam dunia Islam berarti bahwa dunia Islam ini adalah suatu dunia tempat pengelompokan-pengelompokan sosial yang sampai kini kurang lebih hidup terisolasi satu sama lain, masing-masing membentuk dirinya sendiri dan dunia pemikiran absolutnya sendiri. Tetapi sekarang, dalam satu atau lain bentuk, bergabung satu sama lain. Yang sebelumnya kurang lebih memenuhi dirinya sendiri, dan akhirnya, berbagai kelompok yang berhubungan dengan pekerjaan dan kelompok-kelompok intelektual dalam dunia yang didiferensiasikan secara paling cermat ini, semua itu sekarang meninggalkan keadaan cukup diri dan puas diri yang membenarkan dirinya begitu saja, dan terpaksa memertahankan diri mereka dan gagasan-gagasan mereka di hadapan serangan sengit dari kelompok-kelompok yang heterogen itu. Dengan sosiologi pengetahuan, seseorang tidak boleh menghadapi lawannya dengan cara yang biasa yaitu dengan langsung menghadapi argumen-argumen orang lain. Ia terutama berusaha memahami orang lain dengan mendefinisikan perspektif keseluruhan dan melihat perspektif ini sebagai suatu fungsi dari suatu posisi sosial tertentu.

Karena itu, pemikiran an-Na'im sesungguhnya adalah hasil pemboyongan tradisi keilmuan Barat untuk menyelesaikan masalah internal Sudan dan Islam. Realitas sosial, politik, ekonomi, dan budaya Sudan, serta realitas Eropa dan Amerika sama-sama membentuk pemikiran an-Na'im.

Kedua, dalam kaca mata history of idea, pemikiran an-Na'im sesungguhnya mempunyai kesamaan dengan pemikiran Taha, gurunya. Sebagaimana diketahui pemikiran an-Na $\mathrm{im}$ tentang: harus ada sharî́ah baru yang didasarkan pada naskh atau penghapusan ayatayat madaniyah oleh ayat-ayat makkîyah yang menekankan kebebasan beragama, kesetaraan laki-laki dan perempuan, antiperbudakan, larangan penggunaan kekuatan terhadap negara lain, konstitusionalisme, dan sekularisasi, sesungguhnya ia ambil dari pemikiran Taha dalam beberapa tulisannya. Naskh dari Second Message of Islam, konstitusionalisme dari Usus Dustûr al-Sûdân, dan sekularisme dari platform Partai Republikan. 
Seorang John O. Voll, misalnya, mengatakan bahwa an-Na'im telah mengembangkan kembali prinsip-prinsip umum Taha ke dalam analisis konkret tentang penerapan prinsip-prinsip itu dalam hukum publik Islam. Buku an-Na'im, Toward an Islamic Reformation, di mana ia secara cerdas mengenalkan Second Message of Islam, adalah sumber utama tentang kritik pemikiran Republican dalam ranah aturan dan praktik sharî‘'ah tentang keadilan kriminal, hak asasi manusia, dan hukum internasional. ${ }^{22}$

Namun demikian, bukan berarti tidak ada perbedaan antara anNa'im dan Taha. Pemikiran Țaha dalam hal ibadah dan tasawuf sangat dan lebih berkembang dari pada dalam hal hukum publik dan pemerintahan. Inilah yang membedakan Taha dengan an-Na'im, muridnya, yang sama sekali tidak menyinggung ibadah dan tasawuf, kecuali tentang pernikahan, itupun kalau fiqh nikah dimasukkan dalam kitâb al-ibâdah. Memang diketahui bahwa meskipun sebagai seorang pemimpin partai kecil, the Islamic Republican Party, yang gagal dalam pemilihan umum Sudan selama tahun 1950-an, Țaha juga masih sempat meletakkan dasar pendekatan baru dalam pemikiran Islam tentang hukum publik dan perkembangan sosial. ${ }^{23} \mathrm{Hal}$ ini menunjukkan bahwa an-Naim dan Taha berbeda perhatian dalam hal ibadah, tasawuf, dan satu lagi yang tidak kalah menarik dan dengan yakin Taha mengikutinya, yaitu sosialisme. Ide-ide Țaha memang sebuah sintesis yang kompleks dari teori-teori evolusioner Barat (seperti Hegel dan Marx), mistisisme sufi, dan sumber-sumber hukum Islam, (al-Qur'ân dan al-Sunnah). Tidak bisa dipungkiri bahwa Taha terpengaruh oleh ide-ide evolusioner dialektis dalam beberapa hal. ${ }^{24}$ Ayat-ayat makkiyah yang menjunjung kesetaraan laki-laki dan

\footnotetext{
${ }^{22}$ Voll, "Foreword", dalam al-Na'im, Toward an Islamic Reformation, ix-xii.

23 Dasar dari tesis Taha tentang perkembangan sosial dapat ditemukan di beberapa karya lain yang pernah ditulisnya. Misalnya, al-Dîn wa al-Tanmîyah al-Ijtimấîyah (Religion and Social Development), (Omdurman: t.p., 1974). Pemikiran Taha tentang Islam dan hukum publik ada dalam al-Thawrah al-Thaqâfîyah (The Cultural Revolution), (Omdurman: t.p., 1972), dan Tarîq Muhammad (The Path of Muhammad), edisi vii (Omdurman: t.p., t.th.).

24 Memang sedikit sekali contoh keterpengaruhan Taha oleh Hegel dan Marx, namun demikian untuk sekadar mencari informasi lebih lanjut dapat dilihat misalnya Avineri Shlomo, The Social and Political Thought of Karl Marx (Cambridge: Cambridge University Press, 1978) dan Karl Marx, "Contribution to the Critique of Hegel's Philosophy of Right”, dalam Robert Tucker (ed.), The Marx-Engels Reader (New York: New York Press, 1978).
} 
perempuan dan kebebasan sipil dianggap Taha sebagai versi dari evolusionisme sebagaimana dalam sosialisme. ${ }^{25}$

An-Na'im tidak pernah mengusulkan sosialisme sama sekali. Sebagai alumni Inggris, ia juga tidak pernah menyebut-nyebut atau mengutip Marx, pemikir sosialis Jerman itu. Perbedaan perhatian antara Taha yang lebih ke arah ibadah dan tasawuf di satu sisi dan an$\mathrm{Na}$ 'im yang lebih ke arah konstitusionalisme dan sekularisme di sisi lain, padahal sama-sama berangkat dari naskh, menurut peneliti, adalah akibat pendidikan Inggris an-Naim. Sebagaimana diketahui, pada umumnya para pemikir Inggris memerintahkan suatu uraian yang lugas dan merasa curiga terhadap setiap pendekatan yang terlalu spekulatif. Mereka cenderung pada analisis, bukan sintesis. Suatu aliran filsafat Inggris yang khas adalah empirisme (John Lock dan David Hume, misalnya). Seperti tersirat dalam namanya, empirisme mementingkan pengalaman (kata Yunani empiria berarti "pengalaman indrawi"). Filsuf-filsuf Inggris mengutamakan hubungan antara filsafat dan ilmu pengetahuan. Pada umumnya, mereka bersifat antimetafisis. Sementara Taha, tidak pernah mengenyam pendidikan di Inggris. Di negaranya sendiri, ia lebih tertarik pada pemikiran Jerman, karenanya perhatiannya lebih ke arah metafisik, tasawuf misalnya.

Satu hal yang barangkali tidak disadari banyak orang adalah bahwa konsep pemikiran pemberlakuan hukum Islam an-Nacim melalui apa yang disebutnya dengan public reason, sesungguhnya sama dengan konsep masyarakat moral milik Immanuel Kant, seorang filsuf Jerman. Sebagaimana diketahui, an-Na'im mengatakan bahwa normanorma agama dapat dikonversi menjadi hukum negara, jika memang ditemukan alasan sekular untuk itu, atau dalam bahasa lain, jika norma-norma agama telah lolos dalam perdebatan nasional yang mengedepankan public reason. ${ }^{26}$ Padahal jauh-jauh sebelumnya, Kant

\footnotetext{
${ }^{25}$ Lihat SCP, al-Marxîyah, 18.

${ }^{26}$ Pemisahan Islam dan negara, masih kata al-Naim, harus dilakukan dengan tetap mengakui fungsi publik Islam dan pengaruhnya dalam pembuatan kebijakan publik dan undang-undang. Ketegangan yang terjadi akan diselesaikan melalui upaya pemunculan public reason (nalar publik) dalam kerangka konstitusionalisme, HAM, dan kewarganegaraan. Keduanya harus dipisahkan, namun tetap memertahankan hubungan antara Islam dan politik, melalui apa yang disebut sebagai public reason. Prinsip ini memungkinkan penerapan prinsip-prinsip Islam dalam kebijakan publik secara legitimate, namun tetap tunduk pada prinsip-prinsip ketatanegaraan yang berlaku, serta menjamin kesetaraan hak setiap warga negara tanpa membedakan
} 
sudah mengatakan bahwa ada public reason yang siap mengharmoniskan hubungan dua otoritas yang berbeda, akal dan wahyu. Ketika melihat agama, ia meyakini bahwa meski keduanya berbeda otoritas, sesungguhnya ada hubungan yang penting dan mendesak. Hubungan itu tidak selalu berupa konflik, bahkan fungsi akal publik (public reason) yang layak harus memasukkan rujukanrujukan wahyu. Yang ia maksud sebagai public reasoning adalah penalaran yang dilakukan tanpa batasan yang dipaksakan oleh berbagai otoritas lain sehingga memastikan universalitas akal. ${ }^{27}$

Perkataan an-Na'im yang mengutip Joseph Schacht bahwa para ahli fiqh historis tidak membedakan hukum Islam menjadi privat dan publik, mereka hanya membedakannya menjadi hak Tuhan dan hak manusia, ${ }^{28}$ menurut peneliti, sesungguhnya juga merupakan bukti bahwa an-Naim berbeda dengan Taha karena Taha masih memandang budûd sebagai bagian dari hukum pidana yang masih relevan.

Selain kenyataan bahwa Taha sebagai history of idea bagi an-Na'im, sesungguhnya semakin jelas bahwa kekuatan yang mendasari sikap

agama, ras, suku, gender, dan ideologi politik. Umat Islam masih bisa mengajukan kepada negara agar mengadopsi prinsip-prinsip sharî‘ah sebagai kebijakan publik dan menetapkannya menjadi undang-undang atau peraturan melalui public reason.

${ }^{27}$ Sedang private reason adalah setiap penggunaan akal yang dibatasi oleh otoritas luar. Ia membedakan antara agama (religion) dan keimanan (faith). Ia menyatakan bahwa urusan religion sebenarnya adalah urusan public reason, sedang urusan faith adalah urusan private reason. Peneliti dapat menyimpulkan apa yang diutarakan Kant sebagai berikut: Pertama, bahwa tidak ada konflik fundamental antara akal dan wahyu. Percaya bahwa ada Tuhan yang mengharmonisasikan aktivitas moral manusia dan hukum alam natural, sama saja dengan berpendapat dan meyakini bahwa ada harmonisasi yang esensial antara akal dan wahyu. Kedua, akal dan wahyu adalah berbeda satu sama lain, di mana akal kemudian dibedakan menjadi: public dan private. Ketika seseorang berbicara atas nama agama, sesungguhnya ia menggunakan akal privatnya, dan ketika ia berbicara atas nama filsafat tentang agama, ia menggunakan akal publiknya. Ketiga, sementara wahyu dan akal berbeda, Kant melihat dua jenis otoritas itu bekerja secara harmonis dalam membangun dan mengembangkan moral masyarakat. Akal mengajak untuk patuh dan bekerja secara kritis dalam menilai ajakan-ajakan kepatuhan itu. Sedang wahyu menyediakan ide bahwa kepatuhan manusia itu sesuai dengan kehendak Tuhan. Karenanya komunitas moral tidak hanya mungkin tetapi memang dikehendaki. Hubungan harmonis antara akal dan wahyu adalah penting bagi berbagai harapan pemberdayaan moral dalam ranah publik. Lihat Phil Enns, "Reason and Revelation: Kant and the Problem of Authority”, Int J Philos Relig, 62 (2007), 103-114.

${ }^{28}$ Ibid., 5. 
teoretis an-Na'im bukan semata merupakan sesuatu yang individual semata, yakni tidak berasal dari proses individu menyadari kepentingannya dalam arus pemikiran, akan tetapi lebih berasal dari tujuan-tujuan kolektif suatu kelompok yang mendasari pemikiran individu, dan dalam hal ini an-Na'im hanyalah berpartisipasi dalam pandangan yang telah digariskan sebelumnya. Karenanya, dapat diketahui bahwa sebagian besar pemikiran tidak dapat dimengerti secara betul selama kaitannya dengan kehidupan atau dengan implikasi sosial kehidupan manusia tidak diperhitungkan. Karena itu, dapat dipahami bahwa latar belakang sosial ini muncul sebagai kekuatan yang tidak kelihatan yang mendasari pemikiran an-Na'im. Peneliti menyadari bahwa pemikiran an-Na'im bukanlah hasil ilham terisolasi dari dirinya sendiri sebagai pemikir. Pengalaman-pengalaman historis kolektif rakyat Sudan, atau khususnya pengikut Republikan yang diandaikan an-Na'im, namun tanpa syarat dianggap sebagai "pikiran kelompok", sesungguhnya mendasari tilikan mendalam anNaiim.

Ketiga, kehidupan sosial masyarakat Cambridge yang sangat plural dari segi agama, di mana di satu kota kecil itu hidup berbagai anggota masyarakat dari latar belakang agama yang berbeda-beda, lengkap dengan bangunan tempat ibadah berbagai agama itu (baca: Yahudi, Nasrani, Islam, Budha, Hindu, dan juga sekular), membuat an-Na'im berpikir toleran dan semakin mantap dalam upayanya menegakkan standar HAM internasional.

Universitas Cambridge sendiri telah memenangkan 80 penghargaan nobel lebih banyak dari universitas lain di dunia. Hal ini, menurut peneliti, juga mendorong an-Na'im untuk menjadi penulis yang produktif, prolific writer. Nyatanya, hal ini terlihat dari banyaknya jumlah tulisan yang ia buat mulai dari artikel pendek dan book review, artikel panjang dan chapter, hingga buku yang terpublikasikan. Jika dihitung, sesuai dengan yang diakuinya dalam website pribadinya, dari tahun 1974 hingga 2007, total tulisannya sekitar 68 buah. Walhasil, Cambridge, kota yang terkenal sebagai peraih nobel terbanyak dan mempunyai jumlah publikasi ilmiah terbanyak di dunia itu pasti membuat an-Naim semakin matang dalam menulis.

Selain kenyataan di atas, tidak dapat diragukan lagi bahwa sekularisme di Cambridge sudah muncul abad ke-18 dan praktis sudah berhasil di Inggris. Hal ini pasti membuat an-Na'im tidak perlu jauhjauh belajar sekularisme. 
Keempat, di Edinburgh Skotlandia, an-Na'im memang relatif kurang diuntungkan karena suhu politiknya yang tidak menentu dengan adanya tuntutan untuk merdeka dari Inggris Raya. Namun demikian, perbedaan status sosial yang sekarang mulai tidak terlihat di satu sisi, tetapi masih maraknya pernikahan yang tidak membutuhkan restu orang tua, tidak pula menyaratkan saksi-saksi di sisi lain, merupakan realitas sosial yang nyata. Sebagaimana diketahui, pada abad XVIII, di Skotlandia, ada pernikahan yang hanya sekadar "sebuah bisnis yang kompetitif, pernikahan yang irregular but legal, yaitu pernikahan yang cukup dibuat oleh pasangan yang setuju untuk menikah atau dibuat berdasarkan janji untuk menikah yang diikuti dengan seks. Inggris dan Wales yang sama-sama negara bagian Britania memang telah menghapus semua bentuk pernikahan ini, tetapi hukum Skotlandia tetap mengakuinya. Peneliti mengira pemikiran an-Na'im tentang pernikahan mendapat alasan sosiologisnya dari pernikahan masyarakat Skotlandia jenis ini.

Kelima, kehidupan sosial masyarakat Atlanta, dan Amerika pada umumnya, memang diwarnai politik rasial, di mana Amerika Serikat menghadapi banyak problem berkaitan dengan urbanisasi besarbesaran masyarakat kulit hitam. Karena itu, orang Afrika Amerika di Amerika Serikat sering kali diisolasi dan karenanya, miskin akses terhadap pekerjaan, barang-barang, dan juga pelayanan yang memungkinkan kehidupan mereka menjadi lebih baik. Politik rasial ini terbukti dengan: gagalnya penyelesaian kasus pembunuhan terhadap orang-orang Afrika Amerika; kebijakan pemisahan pemukiman antara kulit putih dan kulit hitam; pencabutan hak pilih kulit hitam 1908; dan perbedaan pelayanan publik.

Peneliti memandang posisi an-Na'im sendiri diuntungkan, tidak seperti orang Afrika Amerika yang lain. Mengikuti Du Bois, sesungguhnya dari sekian banyak orang Afrika Amerika itu, ada yang dapat disebut Black Elite. ${ }^{29}$ Mereka adalah para profesional dan pengusaha. Du Bois sendiri menyebutnya best classes atau aristocrats. Ia mengindikasikan bahwa para elite itu terpisah dan berbeda dari sembarang orang hitam Philadelphia, karena mereka memang ingin membedakan diri dari yang lain. Mereka mempunyai sistem nilai yang

${ }^{29}$ Lihat David Levering Lewis, W.E.B. Du Bois: Biography of a Race, 1816-1919 (New York: Henry Holt and Company, 1993), 209. 
berbeda dan sudah menghabiskan banyak waktu dan energi untuk menghadapi ketidakmenentuan ekonomi. ${ }^{30}$

Namun demikian, politik rasial Amerika pada umumnya tetap menghantui orang Afrika Amerika secara keseluruhan, termasuk an$\mathrm{Na}$ im. Apa yang mereka dambakan ketika mereka berusaha melepaskan belenggu perbudakan di awal migrasi mereka dan mengharapkan status kewarganegaraan penuh di Amerika, tidak sepenuhnya terwujud. Mereka harus tercerabut dari akar nasionalitas, budaya, dan agamanya. Mereka harus berjuang mendapatkan keadilan sosial. Posisi politik mereka tidak pernah menguntungkan. Hak asasi mereka terancam. Mereka harus sadar bahwa eksistensinya merupakan ancaman bagi hegemoni Euro Amerika dan telah memengaruhi arah politik negara. Khusus yang Muslim, nasib mereka harus diperparah dengan berbagai stigma, prejudice, serta islamophobia yang berujung kepada tindakan diskriminatif dan intoleransi. Apa yang an-Na'im pikirkan tentang hak-hak sipil, HAM, dan negara sekular adalah perjuangannya melawan ketidakadilan ras terhadap komunitasnya (Afrika Amerika) untuk mendapatkan hak-hak sipil, posisi politik, dan tidak tercerabut dari akar nasionalitas, budaya, dan agamanya, serta menumbangkan stigma negatif Amerika terhadap Islam, dan membangun citra "Muslim yang baik", sebagai perlawanan terhadap islamophobia yang diskriminatif dan intoleran.

Georgia sendiri, sebagai negara bagian Amerika Serikat, telah sangat sekular dengan dicetuskannya kebijakan bahwa negara telah menyerahkan urusan agama kepada masing-masing warga dan tidak untuk membawanya ke ranah sosial. Kebijakan dimaksud juga didukung mayoritas warga Georgia, terbukti dengan protes keras American United for Separation of Church and State terhadap kegiatan doa minta hujan di stadion umum, dan juga terhadap dihapusnya pelajaran teori evolusi di sekolah-sekolah publik dan menganggapnya sebagai upaya bermotif agama. Lagi-lagi an-Na'im dapat belajar tentang kesetaraan ras yang menuntut penegakan HAM dan tentang sekularisme dari kondisi sosial di mana ia hidup sekarang. Tentu sekularisme sebagaimana yang ia pahami dan ia propagandakan sekarang, karena sebagaimana diketahui, bahwa di Amerika lebih banyak guru besar yang agamis dari pada yang atheis, yang mengandaikan bahwa dalam dunia akademik-sebagaimana

\footnotetext{
${ }^{30}$ Lihat Du Bois, The Philadelphia Negro: A Social Study (Philadelphia: University of Pennsylvania, 1899), 100, 311, dan 316-318.
} 
masyarakat umum Amerika-sekularisasi memerlukan lebih banyak privatisasi keimanan agama dari pada penyingkiran terhadap agama. ${ }^{31}$

\section{Gambar}

\section{Determinasi Eksistensial Pemikiran an-Nacim}

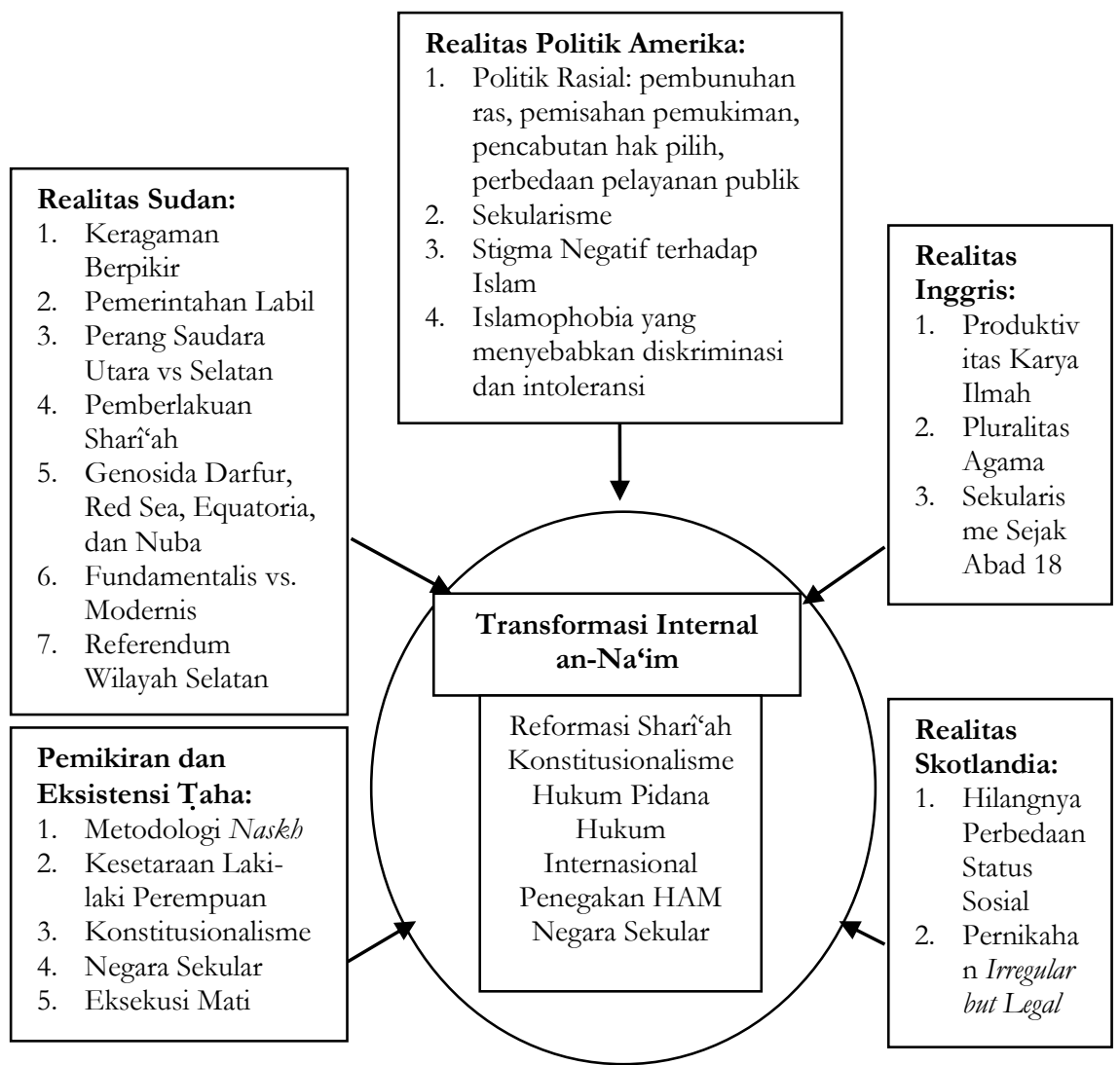

\section{Penutup}

Dari berbagai realitas penting yang mengitari an-Na'im itu, menurut peneliti, realitas politik Amerika yang dominan deterministik terhadap produk pemikirannya. Bila dibanding realitas sosial lain yang juga deterministik, maka ibarat Sudan dan Taha meletakkan batu

31 Lihat angka hasil penelitiannya dalam Neil Gross dan Solon Simmons, "The Religiosity of American College and University Professor", Sociology of Religion, Vol. 70, No. 2 (2009), 101-129. 
pondasinya, Inggris menyiapkan rumahnya, maka Amerika membuat produksinya.

Indikasi terhadap dominannya Amerika terhadap produk pemikiran hukum Islam an-Naim adalah melimpahnya karya-karya an-Na'im ketika ia sudah berada di Amerika. Hanya satu karya yang, menurut pelacakan peneliti, ditulisnya ketika ia sedang dalam proses kepindahannya ke Amerika, yaitu terjemah atas karya gurunya, Taha, The Second Message of Islam.

Selain itu, pemikirannya tentang HAM dan negara sekular sangat masuk akal bila dipandang dalam konteks keberadaannya sebagai orang Afrika Amerika Muslim yang sedang berjuang, paling tidak untuk komunitasnya, mendapatkan hak-hak sipil, posisi politik, memertahankan diri agar tidak tercerabut dari akar nasionalitas, budaya, dan agama, merehabilitasi Islam dari stigma dan prejudice, menolak islamophobia yang berujung pada tindakan diskriminatif dan tidak toleran, serta menjadi Muslim yang baik dengan cara berpikir Barat dan mendeklarasikan diri sebagai sekular.

\section{Daftar Rujukan}

An-Na'im, Abdullahi Ahmed. "Eritrean Independence and African Constitutionalism: A Sudanese Perspective", dalam Amare Takle (ed.), Eritrea and Ethiopia: from Conflict to Cooperation. Lawrenceville, NJ, USA: The Red Sea Press, 1994.

----. Proselytization and Communal Self-Determination in Africa. New York: Orbis Books, 1999.

-----. "Religious Minorities under Islamic Law and the Limits of Cultural Relativisme", Human Rights Quarterly, 23, 2001.

----. "Shari'a and Islamic Family Law: Transition and Transformation", dalam Abdullahi Ahmed an-Na'im (ed.), Islamic Family Law in Changing World: A Global Resource Book. London: Zed Books, 2002.

-----. "Shari'a and Positive Legislation: Is an Islamic State Possible or Viable?", Makalah Public Lecture The Application of Shari'ah and The Issue of Human Rights in Muslim World, UIN Syarif Hidayatullah Jakarta, 4 Januari 2003.

----. "Toward an Islamic Reformation: Responses and Reflections", dalam Tore Lindholm dan Kari Vogt (eds.), Islamic Law Reform: Challenges and Rejoinders. Oslo, Norway: Norwegian Institute of Human Rights, 1993. 
-----. Toward an Islamic Reformation: Civil Liberties, Human Rights, and International Law. Syracuse: Syracuse University Press, 1990.

Berger, Peter., dan Luckmann, Thomas. The Social Construction of Social Reality: A Treatise in the Sociology of Knowledge. England: Penguin Books, 1966.

Bois, Du. The Philadelphia Negro: A Social Study. Philadelphia: University of Pennsylvania, 1899.

Coulson N.J. A History of Islamic Law. Edinburgh: Edinburgh University Press, 1991.

Duran, Khalid. "An Alternatif to Islamism: The Evolutionary Thought of Mahmud Taha", Cross Currents, 42, Winter 1992.

Enns, Phil. "Reason and Revelation: Kant and the Problem of Authority", Int J Philos Relig, 62, 2007.

Gross, Neil., dan Simmons, Solon. "The Religiosity of American College and University Professor", Sociology of Religion, Vol. 70, No. 2, 2009.

http://www.law.emory.edu/aannaim/Diakses tanggal 29 Oktober 2014.

Lewis, David Levering. W.E.B. Du Bois: Biography of a Race, 1816-1919. New York: Henry Holt and Company, 1993.

Mahfud MD, Moh. Dasar dan Struktur Ketatanegaraan Indonesia. Yogyakarta: Rineka Cipta, 2001.

Mahmoud, Mahgoub el-Tigani. State and Religion in the Sudan: Sudanese Thinkers. New York: The Edwin Mellen Press, 2003.

Mannheim, Karl. Ideologi dan Utopia: Menyingkap Kaitan Pikiran dan Politik, terj. F. Budi Hardiman. Yogyakarta: Kanisius, 1991.

Marx, Karl. "Contribution to the Critique of Hegel's Philosophy of Right", dalam Robert Tucker (ed.). The Marx-Engels Reader. New York: New York Press, 1978.

Noor, Farish A. "Review Book: Toward an Islamic Reformation: Civil Liberties, Human Right, and International Law", Journal of Muslim Minority Affairs; Pro Quest Religion, Vol. 20, No. 2. Oktober 2002.

SCP, al-Marxîyah wa Qadâyâ al-Thawrah al-Sûdânîyah. Khartoum: Dâr alWașîlah, 1973.

Shlomo, Avineri. The Social and Political Thought of Karl Marx. Cambridge: Cambridge University Press, 1978.

Stark, Warner. The Sociology of Knowledge: An Essay in Aid of a Deeper Understanding of the History of Ideas. London: Routledge, 1998. 